\title{
A review of the 2017 ISKO France Proceedings
}

\author{
Sabine Roux \\ Independent scholar, Toulouse, France \\ E-mail: sab.roux@gmail.com
}

Widad Mustafa El Hadi (Ed.). Fondements épistémologiques et théoriques de la science de l'information-documentation. Actes du 11e colloque ISKO France 2017. London, UK: ISTE Editions, 2018. 462 pp. ISBN ISBN 9781784054878 (print), 9781784064877 (ebook), 88.00 EUR.

This book gathers the papers presented at the $11^{\text {th }}$ edition of the ISKO France colloquium, focused on the theories of the French-speaking pioneers in information and documentation science: Paul Otlet, Eugène Morel, Suzanne Briet, Louise-Noëlle Malclès, Jacques-Emile Dubois, Jean Meyriat, Jean-Claude Gardin, Robert Estivals et Jacques Maniez. The 34 contributions are organized according to the Francophone pioneer on which each contribution is based.

An introductory article by Birger Hjørland recalls the influence of Emile Durkheim and Marcel Mauss in the field of theory and epistemology of classification and how they highlighted the problem of the role of the classifier, deepening our understanding of the cultural and social influences in the act of classifying.

\section{Paul Otlet (1868-1944)}

\section{Influences}

In the article entitled "Universality and utopia in Conrad Gessner and Paul Otlet: historical approximations," the comparison of their works show that Gessner is the founder of modern bibliographic techniques and Bibliography. Otlet used techniques developed by Gessner and created a new branch of knowledge: documentation.

Wouter Van Acker studies the different philosophical doctrines that influenced the vision of "the Universal Book" by Otlet. According to him, positivism is too imprecise to characterize Otlet's theory of documentation; he concludes that "the analytic phase borrowed its theoretical basis foremost from energeticism and monism; the synthetic phase sought laws and structures that celebrated a positivist version of structural objectivity; while the dissemination of the encyclopaedia was framed in spiritualist terms as an instrument of self-development" (p. 236).

Alexandre Fortier and D. Grant Campbell study the relations between normativism and descriptivism in bibliographic description through Otlet's works. 


\section{Mundaneum}

Marcilio de Brito, Salviano Guimarães, Maria Alice Borges and Amel Fraisse offer a comparative analysis between the World City invented by Paul Otlet and Henri La Fontaine and the city of Brasilia designed by the architect Lúcio Costa in 1956. They highlight the role of the architect urbanist, sculptor and painter Le Corbusier in both projects.

Fabrice Papy analyzes the expectations of Paul Otlet concerning the digital mundaneum and the augmented internet.

\section{World Impact}

Barbara Sosinska-Katala in her article, "The impact of Paul Otlet and Suzanne Briet's works on the development of the epistemology of documentation and information science in Poland," analyzes publications of Polish researchers in bibliography, documentation and information sciences. She concludes that though Paul Otlet's theories had a huge influence generally speaking, they had less influence on Polish researchers.

Blanca Rodriguer-Bravo, Maria Simões and Daniel Martinez-Avila's study shows the main influence of the Traité de documentation on the Portuguese- and Spanishspeaking communities of knowledge organization.

\section{Paul Otlet Today}

Rodrigo Bozetti and Regina Marteleto analyze biobanks through a history of the concept of document in the francophone tradition beginning with Paul Otlet and a history of the concept of device.

Starting from Paul Otlet and Suzanne Briet's works on documentation, Alexandre Fortier and Elaine Ménard explore the documentality of the tattoo.

\section{Eugène Morel (1869-1934)}

Librarian and writer, Eugène Morel is interested in the world of libraries and public reading after a trip to England where he was fascinated by the organization and success of the London Free Library. In 1908, he wrote Bibliothèques: essai sur le développement des bibliothèques et de la librairie dans les deux mondes and in 1910, La librairie publique: Quel pédant inventa le mot Bibliothèque laissant le mot français Librairie aux Anglais? He insisted on the social role of libraries and the expanding of audiences and practices. According to Yolande Maury, Eugène Morel's thinking is concretized especially in libraries as third space and learning centers, hybrid structures that offer a "a wide choice of cultural contents and services, taking better account of popular cultures" ["large choix de contenus culturels et de services, prenant mieux en compte les cultures populaires"] (p. 205). His thinking about a documentary organization integrated all types of documents for the general public with a view to democratization. 


\section{Suzanne Briet (1894-1989)}

Michael Buckland highlights the links that unite the biography of Suzanne Briet with her writings. "Suzanne Briet published more than a hundred books and articles. Most of them are conventional papers on bibliography, documentation, or library services. Many others are on the history and literature of the Ardennes region around Charleville-Mézières and the poet Arthur Rimbaud" (p. 11). The purpose is to understand the technical, social and intellectual context to understand the theory developed in Qu'est-ce que la documentation? Michael Buckland concludes by giving research perspectives: "there is work to be done on the history, especially the intellectual history, of bibliography, documentation, and knowledge organization" (p. 14).

Locating the works of Suzanne Briet in the history of access to information, Sylvie Fayet-Scribe envisions Suzanne Briet as the heiress of a genealogy of Frenchspeaking pioneers. According to her, Suzanne Briet "made the document to move into a new semantic and semiological dimension. She helps it to move from an auxiliary status to a dynamic agent of intangible capital in society" ["fait basculer le document dans une nouvelle dimension sémantique et sémiologique. Elle l'aide à passer d'un statut auxiliaire à celui d'un agent dynamique du capital immatériel dans la société"] (p. 23). Sylvie Fayet-Scribe explains the influence of the neo-positivist doctrine, especially from Pierre Duhem, on Suzanne Briet's documentation theory. The perception of the object transforms the document into a sort of reality substitute with multiple mediations.

Muriel Frisch, in the learning context, focuses on the epistemological passage from the notion of document to that of documentation in Suzanne Briet's works.

\section{Louise-Noëlle Malclès (1900-1977)}

Marianne Cailloux proposes an analysis of Louise-Noëlle Malclès's works who was a precursor of the professional library organization. Her reflections are based on the transformation of Paul Otlet's bibliographic thinking into professional documentary mediation.

\section{Jacques-Emile Dubois (1920-2005)}

Christian Bourret, Daniel Laurent and Serge Chambaud made a presentation about Jacques-Emile Dubois "a pioneer in information science and STI (Scientific and Technical Information), with an ever-relevant vision" ["un pionnier des Sciences de l'Information et de l'IST (Information Scientifique et Technique), avec une vision toujours actuelle"] (p. 191). With a background as a chemical engineer, and of resistance during World War II, he is the inventor of DARC information system, (Documentation and Automation of Research of Correlations). 


\section{Jean Meyriat (1921-2010)}

Viviane Couzinet focuses on the construction in France in 1970s of information and communication sciences which is a mix of library and information science, media studies and cultural studies and the leading role of Jean Meyriat who was Director of documentation services at the national political sciences Foundation and Director of studies at EPHE (Ecole Pratiques des Hautes Etudes).

In an interdisciplinary conception of information science, Fernanda Ribeiro and Armando Malheiro Da Silva study the current structure of the iSchools starting from the French approach of information and communication sciences elaborated by Jean Meyriat.

Luciana Corts Mendes explores the emergence of the concept of documentation through Paul Otlet, Suzanne Briet, Jean Meyriat and Roger T. Pédauque's works.

Icléia Thiesen uses the distinction made by Jean Meyriat between "document by intention" and "document by attribution" to define the notion of sensible documentation, documents produced during the period of military governments in Brazil (19641985).

Sylvie Sognos, Cécile Gardiès, Isabelle Couturier, Laurent Escande and Cécile Souriau study the use of types ("genres") of information as defined by Jean Meyriat to think and teach information. In fact, Jean Meyriat proposed a categorization of types ("genres") of information at the intersection between lifetime and functions of information. The qualitative study on knowledge analysis of the teacher is based on this categorization that distinguishes scientific and technical information, media information, cultural information and intelligence information.

\section{Jean-Claude Gardin (1925-2013)}

José-Augusto Guimarães analyses Jean-Claude Gardin's interdisciplinary method based on the triangle: documentation, linguistics, and logic. This method helps to elaborate documentary analysis and documentary language concepts.

Roger Bautier focuses on the logistic program of Jean-Claude Gardin and his extension in the semantic web.

Studies on the Francophone influence in Brazilian Knowledge Organization show that the new generation of Brazilian researchers are influenced by Gardin's work (his conception on documentary analysis with interdisciplinary approach and focus on processes and not only on products) and also Otlet's work on bibliography.

Marilda Lopes Ginez de Lara, Johanna Wilhelmina Smit, Maria de Fatima Gonçalves Moreira Talamo focus on the process of documentary analysis by JeanClaude Gardin. "The [Documentary Analysis] process highlights the importance of using semantic analysis methods that are more objective and stricter than the traditional instruments that guided empirical interpretation in Humanities. Gardin was 
a pioneer in the 1970s in recognizing the importance of language in scientific production and the basic need for an interpretative methodological apparatus of logicalsemantic nature not associated with any one discipline" (p. 85). According to them, "Gardin was one of the first to propose ways to promote what is known today as semantic mapping and interoperability" (p. 91).

Julian Warner focuses on Jean-Claude Gardin's article "Document analysis and linguistic theory," published in 1973, and questions its relevance today. According to him, Gardin's analysis of the structure of indexing languages remains valuable, "Information science and linguistics can then mutually and productively inform each over, once the computational metaphor is transcended" (p. 355).

\section{Robert Estivals (1927-2016)}

As a part of a project of identification and digitization of Robert Estivals's works, Olivier Le Deuff and Franck Cormerais discuss theoretical and practical aspects of Robert Estivals's writings following Paul Otlet's works about bibliology and bibliometrics.

\section{Jacques Maniez}

Michèle Hudon analyses an important article written by Jacques Maniez "Des classifications aux thésaurus: du bon usage des facettes" ["From classifications to thesauri: on the good use of facets"]. In this article, he demonstrated the ambiguity of the nature of the facet in Raganathan's theory while underlining its importance in contemporary information systems. Jacques Maniez proposed a terminological solution to the ambiguity of the facet in Raganathan's theory by distinguishing two categories of facets: "categorial facets, applicable to any classification of concepts independently of the domains, and structural facets to designate the essential components of an entity or subject" ["les facettes catégorielles, applicables à toute classification de concepts indépendamment des domaines, et les facettes structurelles pour désigner les composantes essentielles d'une entité ou d'un sujet"] (p. 80).

In "The definition of subjects in times of hashtag activism: documentary discourse and discursive indexing in dynamic informational environments", Maria Aparecida Moura uses Muriel Amar and Jacques Maniez's indexing theory to analyze the complexity in the definition of subject in processes of knowledge organization. The analysis of hashtag activism '\#BlackLivesMatter' showed "the strategic alliance among information resources and the representation of documents through the reconstitution of discursive space and understanding of subjects in dynamic contexts" (p. 401). 